\title{
Comparative study of abdominal hysterectomy and vaginal hysterectomy in non-descent cases a prospective study
}

\author{
Kalpana Mehta ${ }^{1}$, Om Prakash${ }^{1}$, Dharmendra Singh Fatehpuriya ${ }^{1 *}$, Leena Verma ${ }^{2}$
}

\author{
${ }^{1}$ Department of Obstetrics and Gynecology, S. N. Medical College, Jodhpur, Rajasthan, India \\ ${ }^{2}$ Department of Pathology, S. N. Medical College, Jodhpur, Rajasthan, India
}

Received: 27 February 2017

Accepted: 02 March 2017

\author{
*Correspondence: \\ Dr. Dharmendra Singh Fatehpuriya, \\ E-mail: krish13121987@gmail.com
}

Copyright: (C) the author(s), publisher and licensee Medip Academy. This is an open-access article distributed under the terms of the Creative Commons Attribution Non-Commercial License, which permits unrestricted non-commercial use, distribution, and reproduction in any medium, provided the original work is properly cited.

\begin{abstract}
Background: In the present times, the emphasis on minimally invasive surgery has lead to a resurgence of interest and importance of $\mathrm{VH}$ for non-prolapsed indications i.e. non-decent vaginal hysterectomy (NDVH) as the scar less hysterectomy. It has several benefits over abdominal hysterectomy in terms of cosmetic advantages, lesser postoperative morbidity and faster recovery. The objectives of the study was to compare and assess various factors like operative duration of surgery, intra operative blood loss, intra operative and post-operative complications, postoperative analgesia requirement, post-operative ambulation and duration of post-operative hospital stay and to put forward best route of hysterectomy.

Methods: Hundred cases fulfilling, the selection criteria were included in the study. Patients were randomly divided in two groups-NDVH (non-decent vaginal hysterectomy) and abdominal hysterectomy.

Results: Operative time, intra operative blood loss and post-operative morbidity was less in NDVH groups.

Conclusions: Non-decent vaginal hysterectomy is a better alternative to abdominal hysterectomy in cases with benign pathology of the uterus, uterine size $<14$ weeks, uterus with good mobility and adequate vaginal access.
\end{abstract}

Keywords: Abdominal hysterectomy, Non-decent vaginal hysterectomy

\section{INTRODUCTION}

Hysterectomy is the commonest major gynecological surgery performed in women. Traditionally, the uterus has been removed by abdominal route that gives the opportunity to inspect the ovaries and vaginal route is being reserved for pelvic organ prolapse. Now emphasis on minimally invasive surgery has lead to a resurgence of interest and importance of $\mathrm{VH}$ for non-prolapse indications i.e. non-descent vaginal hysterectomy (NDVH) as the scarless hysterectomy.

In the past, surgeons performed approximately $75 \%$ of these procedures abdominally despite reported to have a higher incidence of complication, a longer length of hospital stay and convalescence and greater hospital charges but now data obtained from hysterectomy surveillance studies show that during the early 1990s, there was a $10 \%$ to $15 \%$ decline in the percentage of abdominal hysterectomy performed. ${ }^{1-5,7}$

\section{Factors limiting the use of vaginal hysterectomy}

The absence of formal practice guidelines that clearly identify appropriate candidates for vaginal hysterectomy, abdominal hysterectomy and laparoscopically assisted vaginal hysterectomy, a lack of training and experience in vaginal and laparoscopic techniques, a reluctance to perform vaginal surgery when the uterus is significantly enlarged in nulliparous women, or in the absence of uterine prolapse. ${ }^{4,6,8-11}$ 


\section{Aims and objectives of recent study is to assess and compare various factors like}

Operative duration of surgery, Intra operative blood loss, Intra operative and post-operative complications, postoperative analgesia requirement, Post-operative ambulation and duration of post-operative hospital stay.

\section{METHODS}

A prospective study was carried out to compare the vaginal hysterectomy and abdominal hysterectomy in non- descent cases. This study was done on 100 patients scheduled to undergo hysterectomy for benign conditions attended to Dr. S.N. Medical College, Jodhpur Raj. Cases for the study were taken from those admitted for hysterectomy at outdoor fulfilling criteria via history and thorough examinations \& aided by ancillary measures like pap smear, cervix biopsy, D\&C and USG abdomen pelvis.

\section{RESULTS}

Most of Patients were in age group 40-49 years (56\% in TAH group and $70 \%$ in NDVH group) (Table 1).

Table 1: Distribution of cases according to age.

\begin{tabular}{|c|c|c|c|}
\hline $\begin{array}{l}\text { Age in } \\
\text { years }\end{array}$ & $\begin{array}{l}\text { No. of } \\
\text { cases of } \\
\text { TAH }\end{array}$ & $\begin{array}{l}\text { No. of cases } \\
\text { of NDVH }\end{array}$ & $\begin{array}{l}\text { Total No. } \\
\text { of cases }\end{array}$ \\
\hline $30-39$ & 08 & 05 & 13 \\
\hline $40-49$ & 28 & 35 & 63 \\
\hline $50-59$ & 13 & 08 & 21 \\
\hline$>60$ & 01 & 02 & 03 \\
\hline Total & 50 & 50 & 100 \\
\hline
\end{tabular}

No significant difference in parity between both groups seen (Table 2).

Table 2: Distribution of cases according to parity.

\begin{tabular}{|llll|}
\hline Parity & $\begin{array}{l}\text { No. of cases } \\
\text { in TAH } \\
(\%)\end{array}$ & $\begin{array}{l}\text { No. of cases in } \\
\text { NDVH }(\%)\end{array}$ & $\begin{array}{l}\text { Total no. } \\
\text { of cases } \\
(\%)\end{array}$ \\
\hline P1 & $01(2 \%)$ & $1(2 \%)$ & $02(2 \%)$ \\
\hline P2 & $09(18 \%)$ & $12(24 \%)$ & $21(21 \%)$ \\
\hline P3 & $14(28 \%)$ & $12(24 \%)$ & $26(26 \%)$ \\
\hline P4 & $12(24 \%)$ & $13(26 \%)$ & $25(25 \%)$ \\
\hline >P5 & $14(28 \%)$ & $12(24 \%)$ & $26(26 \%)$ \\
\hline Total & 50 & 50 & 100 \\
\hline
\end{tabular}

In this study $26 \%$ cases in TAH groups and $34 \%$ cases in NDVH groups had uterine size $>12$ weeks gestation (Table 3 and Figure 2).

Medical Illness were present in $9(18 \%)$ cases of TAH and $5(10 \%)$ cases of NDVH (Table 4$).$
Table 3: Distribution of cases according to uterine size.

\begin{tabular}{|llll|}
\hline $\begin{array}{l}\text { Size of utert } \\
\text { (in weeks of } \\
\text { gestation) }\end{array}$ & $\begin{array}{l}\text { No. of cases }(\%) \\
\text { TAH of cases }\end{array}$ & $\begin{array}{l}\text { Total no. } \\
\text { in NDH } \\
(\%)\end{array}$ & $\begin{array}{l}\text { of cases } \\
(\%)\end{array}$ \\
\hline 06 & $21(42 \%)$ & $16(32 \%)$ & $37(37 \%)$ \\
\hline 08 & $08(16 \%)$ & $07(14 \%)$ & $15(15 \%)$ \\
\hline 10 & $08(16 \%)$ & $10(20 \%)$ & $18(18 \%)$ \\
\hline 12 & $05(10 \%)$ & $08(16 \%)$ & $13(13 \%)$ \\
\hline 14 & $08(16 \%)$ & $09(18 \%)$ & $17(17 \%)$ \\
\hline Total & 50 & 50 & 100 \\
\hline
\end{tabular}

Table 4: Distribution of cases according to medical illness.

\begin{tabular}{|llll|}
\begin{tabular}{|l} 
Medical \\
disease
\end{tabular} & $\begin{array}{l}\text { No. of } \\
\text { cases in } \\
\text { TAH }(\%)\end{array}$ & $\begin{array}{l}\text { No. of } \\
\text { cases in } \\
\text { NDVH } \\
(\%)\end{array}$ & $\begin{array}{l}\text { Total no. } \\
\text { of cases } \\
(\%)\end{array}$ \\
\hline Diabetes & $02(4 \%)$ & $01(2 \%)$ & $03(3 \%)$ \\
\hline Hypertension & $02(4 \%)$ & $03(6 \%)$ & $05(5 \%)$ \\
\hline Severe anemia & $01(2 \%)$ & $01(2 \%)$ & $02(2 \%)$ \\
\hline Heart disease & $01(2 \%)$ & $00(0 \%)$ & $01(1 \%)$ \\
\hline Hypothyroidism & $03(6)$ & $00(0 \%)$ & $03(3 \%)$ \\
\hline Total & $09(18 \%)$ & $05(10 \%)$ & $14(14 \%)$ \\
\hline
\end{tabular}

In this study one case in TAH and three cases in NDVH groups were having history of previous one cesarean section. One case of TAH had history of previous two cesarean sections while no such case in NDVH group.

Table 5 show fibroids were the most common indication of Hysterectomy in both group (64\% cases of TAH and $56 \%$ cases of NDVH). DUB was the $2^{\text {nd }}$ most common indication in both group (22\% cases of TAH and $36 \%$ cases of NDVH. Adenomyosis was the indication in $10 \%$ cases of TAH and $6 \%$ cases of NDVH. In $4 \%$ cases of TAH and $2 \%$ cases of NDVH endometrial polyp was the indication of hysterectomy.

Post-menopausal bleeding was the indication of hysterectomy in one case of NDVH.

Table 5: Distribution of cases according to indications of surgery.

\begin{tabular}{|llll|}
\hline $\begin{array}{l}\text { Indication of } \\
\text { surgery }\end{array}$ & $\begin{array}{l}\text { No. of } \\
\text { cases in } \\
\text { TAH }(\%)\end{array}$ & $\begin{array}{l}\text { No. of cases } \\
\text { in NDVH } \\
(\%)\end{array}$ & $\begin{array}{l}\text { Total no. } \\
\text { of cases } \\
(\%)\end{array}$ \\
\hline Fibroids & $32(64 \%)$ & $28(56 \%)$ & $60(60 \%)$ \\
\hline DUB & $11(22 \%)$ & $17(34 \%)$ & $28(28 \%)$ \\
\hline Adenomyosis & $05(10 \%)$ & $03(6 \%)$ & $08(8 \%)$ \\
\hline $\begin{array}{l}\text { Endometrial } \\
\text { polyp }\end{array}$ & $02(4 \%)$ & $11(2 \%)$ & $03(3 \%)$ \\
$\begin{array}{l}\text { Post } \\
\text { menopausal } \\
\text { bleeding }\end{array}$ & $00(0 \%)$ & $01(2 \%)$ & $01(1 \%)$ \\
\hline \begin{tabular}{l} 
Total \\
\hline
\end{tabular} & 50 & 50 & 100 \\
\hline
\end{tabular}


Blood loss and operative time were more when we used volume reductive methods. Mean blood loss in VRS were $173 \mathrm{ml}$ while it was $166 \mathrm{ml}$ without VRS. Mean operative time was 72 minute in NDVH with volume reductive surgeries while it was 68 minutes in conventional NDVH. (Table 6).

Table 6: Distribution of cases according to volume reductive surgery.

\begin{tabular}{|llll|}
\hline $\begin{array}{l}\text { Volume } \\
\text { reductive } \\
\text { surgery (VRS) }\end{array}$ & $\begin{array}{l}\text { No. of } \\
\text { cases in } \\
\text { NDVH } \\
(\%)\end{array}$ & $\begin{array}{l}\text { Mean } \\
\text { blood los } \\
(\text { ML) }\end{array}$ & $\begin{array}{l}\text { Mean } \\
\text { duration } \\
\text { of surgery } \\
\text { (MINS) }\end{array}$ \\
\hline Bisection & $07(14 \%)$ & 150 & 68.7 \\
\hline $\begin{array}{l}\text { Morcellation } \\
\text { Enucleation }\end{array}$ & $05(10 \%)$ & 192 & 77.6 \\
\hline $\begin{array}{l}\text { Combined } \\
\text { (Morcellation, } \\
\text { Bisection) }\end{array}$ & $01(2 \%)$ & 195 & 66 \\
\hline No VRS Used & $35(70 \%)$ & 166 & 60.6 \\
\hline
\end{tabular}

In our study bladder injury occurred in one case in either group. No other major intra operative complications were seen in either group. In our study mean blood loss in TAH group is $219.38 \mathrm{ml}$ while mean blood loss in NDVH groups in $168.76 \mathrm{ml}$. So there is significant difference in blood loss between TAH and NDVH. Overall blood loss in NDVH is less compared to TAH (Table 7).

Table 7: Distribution of cases according to intra operative blood loss.

\begin{tabular}{|llll|}
\hline $\begin{array}{l}\text { Mean } \\
\text { blood } \\
\text { loss in (ML }\end{array}$ & $\begin{array}{l}\text { No. of } \\
\text { cases in } \\
\text { TAH) }\end{array}$ & $\begin{array}{l}\text { No. of cases } \\
\text { in NDVH }(\%)\end{array}$ & $\begin{array}{l}\text { Total No. } \\
\text { of cases } \\
(\%)\end{array}$ \\
\hline $50-100$ & 00 & $05(10 \%)$ & $05(5 \%)$ \\
\hline $101-150$ & $11(22 \%)$ & $20(40 \%)$ & $31(31 \%)$ \\
\hline $151-200$ & $18(36 \%)$ & $15(30 \%)$ & $33(33 \%)$ \\
\hline $201-250$ & $09(18 \%)$ & $08(16 \%)$ & $17(17 \%)$ \\
\hline $251-300$ & $09(18 \%)$ & $01(2 \%)$ & $10(10 \%)$ \\
\hline$>300$ & $03(6 \%)$ & $01(2 \%)$ & $04(4 \%)$ \\
\hline
\end{tabular}

In our study mean operative time in TAH group is 77.64 min while mean operative time in NDVH groups is 68.84 min. So, mean operative time is less in NDVH compared to TAH (Table 8).

Table 8: Distribution of cases according to operative time.

\begin{tabular}{|llll|}
$\begin{array}{l}\text { Time in } \\
\text { minutes }\end{array}$ & $\begin{array}{l}\text { No. of } \\
\text { cases in } \\
\text { TAH }(\%)\end{array}$ & $\begin{array}{l}\text { No. of cases } \\
\text { in NDVH } \\
(\%)\end{array}$ & $\begin{array}{l}\text { Total no. } \\
\text { of cases } \\
(\%)\end{array}$ \\
\hline $0-60$ & $10(20 \%)$ & $12(24 \%)$ & $22(22 \%)$ \\
\hline $61-90$ & $38(76 \%)$ & $37(74 \%)$ & $75(75 \%)$ \\
\hline $91-120$ & $02(4 \%)$ & $01(2 \%)$ & $03(3 \%)$ \\
\hline
\end{tabular}

In our study $10 \%$ cases of TAH and $4 \%$ cases of NDVH had post-operative pyrexia, $2 \%$ cases of TAH and $6 \%$ cases of NDVH had post-operative vomiting, $2 \%$ cases in TAH and $4 \%$ cases in NDVH had post-operative UTI, $6 \%$ cases of paralytic ileus, $4 \%$ cases of wound infection, $4 \%$ cases of wound gap and $2 \%$ case of re-suturing were seen in TAH group while no such complications were seen in NDVH groups (Table 9).

Table 9: Distribution of cases according to post operative complications.

\begin{tabular}{|llll|}
\hline $\begin{array}{l}\text { Post- } \\
\text { operative } \\
\text { complications }\end{array}$ & $\begin{array}{l}\text { No. of } \\
\text { cases in } \\
\text { TAH (\%) }\end{array}$ & $\begin{array}{l}\text { No. of } \\
\text { cases in } \\
\text { NDVH }(\%)\end{array}$ & $\begin{array}{l}\text { Total no. } \\
\text { of cases } \\
(\%)\end{array}$ \\
\hline Pyrexia & $05(10 \%)$ & $02(4 \%)$ & $07(7 \%)$ \\
\hline Vomiting & $01(2 \%)$ & $03(6 \%)$ & $04(4 \%)$ \\
\hline Paralytic Ileus & $03(6 \%)$ & $00(0 \%)$ & $03(3 \%)$ \\
\hline UTI & $01(2 \%)$ & $02(4 \%)$ & $03(3 \%)$ \\
\hline Wound gap & $02(4 \%)$ & $00(0 \%)$ & $02(2 \%)$ \\
\hline Re-Suturing & $01(2 \%)$ & $00(0 \%)$ & $01(1 \%)$ \\
\hline $\begin{array}{l}\text { Wound } \\
\text { infections }\end{array}$ & $02(4 \%)$ & $00(0 \%)$ & $02(4 \%)$ \\
\hline
\end{tabular}

In our study $8 \%$ cases of TAH and $4 \%$ cases of NDVH required one unit of blood transfusion post operatively. One cases of TAH and one cases of NDVH required two unit of blood transfusion post-operatively (Table 10).

Table 10: Distribution of cases according to postoperative blood transfusions.

\begin{tabular}{|llll|}
$\begin{array}{l}\text { No of } \\
\text { units of } \\
\text { blood }\end{array}$ & $\begin{array}{l}\text { No. of cases } \\
\text { in TAH } \\
(\%)\end{array}$ & $\begin{array}{l}\text { No. of cases } \\
\text { in NDVH } \\
(\%)\end{array}$ & $\begin{array}{l}\text { Total No. } \\
\text { of cases } \\
(\%)\end{array}$ \\
\hline 01 & $04(8 \%)$ & $02(4 \%)$ & $06(6 \%)$ \\
\hline 02 & $01(2 \%)$ & $01(2 \%)$ & $02(2 \%)$ \\
\hline Total & $05(10 \%)$ & $03(6 \%)$ & $08(8 \%)$ \\
\hline
\end{tabular}

Mean No. of days of analgesia in TAH is 5.44 days while it is 3.28 days in NDVH group (Table 11).

Table 11: Distribution of cases according to post operative analgesia requirement.

\begin{tabular}{|llll|}
$\begin{array}{l}\text { No. of days } \\
\text { of analgesia }\end{array}$ & $\begin{array}{l}\text { No. of } \\
\text { cases in } \\
\text { TAH }(\%)\end{array}$ & $\begin{array}{l}\text { No. of cases } \\
\text { in NDVH } \\
(\%)\end{array}$ & $\begin{array}{l}\text { Total no. } \\
\text { of cases } \\
(\%)\end{array}$ \\
\hline 03 & $02(4 \%)$ & $39(78 \%)$ & $41(41 \%)$ \\
\hline 04 & $07(14 \%)$ & $08(16 \%)$ & $15(15 \%)$ \\
\hline 05 & $12(24 \%)$ & $03(6 \%)$ & $15(15 \%)$ \\
\hline 06 & $25(50 \%)$ & $00(0 \%)$ & $25(25 \%)$ \\
\hline 07 & $04(8 \%)$ & $00(0 \%)$ & $04(4 \%)$ \\
\hline Total & 50 & 50 & 100 \\
\hline
\end{tabular}

In our study, most of cases (66\%) of NDVH got ambulated in $<24$ hrs. post operatively while most of $(50 \%)$ cases in TAH got ambulated in $>48$ hours (Table 12). 
Table 12: Distribution of cases according to postoperative ambulation.

\begin{tabular}{|llll|}
\hline $\begin{array}{l}\text { Post } \\
\text { operative } \\
\text { duration }\end{array}$ & $\begin{array}{l}\text { No. of } \\
\text { cases in } \\
\text { TAH }(\%)\end{array}$ & $\begin{array}{l}\text { No. of } \\
\text { cases in } \\
\text { NDVH }(\%)\end{array}$ & $\begin{array}{l}\text { Total no. } \\
\text { of cases } \\
(\%)\end{array}$ \\
\hline$<24$ hours & $01(2 \%)$ & $33(66 \%)$ & $34(34 \%)$ \\
\hline $24-48$ hours & $24(48 \%)$ & $14(28 \%)$ & $38(38 \%)$ \\
\hline$>48$ hours & $25(50 \%)$ & $03(6 \%)$ & $28(28 \%)$ \\
\hline Total & 50 & 50 & 100 \\
\hline
\end{tabular}

Mean post-operative hospital stay in TAH is 6.52 days while it is 4.28 days in NDVH group so post-operative hospital stay is significantly less in NDVH compared to TAH group (Table 13).

Table 13: Distribution of cases according to post operative hospital stay.

\begin{tabular}{|llll|}
$\begin{array}{l}\text { No. of post } \\
\text { operative } \\
\text { days }\end{array}$ & $\begin{array}{l}\text { No. of } \\
\text { cases in } \\
\text { TAH (\%) }\end{array}$ & $\begin{array}{l}\text { No. of } \\
\text { cases in } \\
\text { NDVH }(\%)\end{array}$ & $\begin{array}{l}\text { Total no. } \\
\text { of cases } \\
(\%)\end{array}$ \\
\hline 03 & $00(0 \%)$ & $05(10 \%)$ & $05(5 \%)$ \\
\hline 04 & $00(0 \%)$ & $35(70 \%)$ & $35(35 \%)$ \\
\hline 05 & $05(10 \%)$ & $05(10 \%)$ & $10(0 \%)$ \\
\hline 06 & $34(68 \%)$ & $04(8 \%)$ & $38(38 \%)$ \\
\hline $\begin{array}{l}1 \text { Week }-2 \\
\text { Weeks }\end{array}$ & $11(22 \%)$ & $01(2 \%)$ & $12(12 \%)$ \\
\hline Total & 50 & 50 & 100 \\
\hline
\end{tabular}

\section{DISCUSSION}

Hysterectomy is the most common gynecological procedure and it is vital to make an evidence based decision to choose an appropriate technique.

Studies of hysterectomy practice show that in the past surgeons performed approximately $75 \%$ of these procedure abdominally despite well documented evidence that, when compared with unassisted vaginal hysterectomy, abdominal hysterectomy was reported to have higher incidence of complications, longer length of hospital stay and convalesance and greater hospital charges. The advantages of vaginal hysterectomy over abdominal hysterectomy have prompted numerous investigations to recommend vaginal hysterectomy for women whose conditions permit the approach. The present study between total abdominal hysterectomy and vaginal hysterectomy in non decent uterus was done with the same interest.

\section{Classic contraindications of $\mathrm{VH}$}

Absolute contraindications

a) Uterus is two big (>280 gm)

b) Vagina is too narrow

- Pubic arch $<90^{\circ}$

- Bituberous diameter $<8 \mathrm{~cm}$. c) The uterus is too high or it does not decent

d) Intra-abdominal conditions contraindicating the vaginal approach - adhesions, endometriosis, adenexal pathology, chronic pelvic pain, history of csection.

\section{Relative contraindication}
a) Nulliparous
b) History of pelvic surgery (other than c-section)
c) Moderately enlarged uterus
d) Indication of oophorectomy

In the present study the mean age of patients In TAH group was 44.7 yrs. and in NDVH group it was 44.94 yrs. This is comparable to studies done by Hwang et al, Ribeiro et al, Silva filho et al which showed mean age of 45 years, 42.3 years, 45 years respectively. ${ }^{13-15}$

In the present study the mean parity in TAH and NDVH group was 3.58 and 3.46 respectively. This is comparable to Bharatnur $\mathrm{S}$ which had mean parity of 3.8 and 3.6 in TAH and NDVH group respectively. ${ }^{16}$

In the present study mean uterine size in gestational weeks was 8.84 in TAH and 9.48 in NDVH and this is comparable to study of Miskry $\mathrm{T}$ which had 7.8 weeks in NDVH as compared to 6.9 weeks in TAH group. ${ }^{17}$ In our study fibroids were the most common indication in both groups and DUB was the second most common indication in both groups. In a study by Shanthini NF et al fibroid were the most common indication in TAH group as in our study but in NDVH group DUB was more common indication in Shanthini ${ }^{18}$ and all other studies. ${ }^{18}$

In the present study volume reductive methods were used in 15 cases. Mean blood loss in de bulking was higher than mean blood loss in conventional NDVH $(173.3 \mathrm{ml}$. v/s $166.8 \mathrm{ml}$.) but still it was less than mean blood loss in TAH (219.38 ml.) Mean operative time in debulking was higher than mean operative time in conventional NDVH (72.73 min. v/s $68.6 \mathrm{~min}$.) but still it was less than mean operative time in TAH (77.64 min.). This is comparable to study of Modi $\mathrm{K}$ et at in which debulking methods were used in 19 cases and mean blood loss in debulking was also more than conventional NDVH $(171.8 \mathrm{ml} . \mathrm{v} / \mathrm{s}$ $89.5 \mathrm{ml}$.) but less than TAH. ${ }^{19}$ Operative duration was also more than in de bulking procedure as compared to conventional NDVH (66.5 $\mathrm{min} \mathrm{v} / \mathrm{s} 36.7 \mathrm{~min})$ but was less than TAH (85 min).

In the present study one case in TAH and three cases in NDVH group were having history of previous one cesarean section. One case of TAH had history of previous two cesarean sections while NDVH group had no such case. A history of previous CS is a significant risk for accidental cystotomy at the time of hysterectomy regard less of approach. We suggest sharp dissection for bladder reflection during a vaginal hysterectomy is preferable to blunt dissection in preventing accidental 
cystotomy, as is the case at laprotomy. In a 1973 review of 621 hysterectomies, Coulam et al concluded that previous pelvic surgery was not a contraindication to vaginal surgery. ${ }^{20}$ In our study bladder injury occurred equally in both groups $(2 \%)$.

Somjita $\mathrm{C}$ et al also reported equal bladder injury in both groups. ${ }^{21}$ We had no case of ureteric injury and bowel injury in either groups as in a study of Chakraborthy $\mathrm{S}$ Somjita et al (08). ${ }^{21}$

In the present study mean blood loss was less in NDVH compared to TAH (168.76 ml v/s $219.38 \mathrm{ml}$.) This is comparable to studies done by Ribeiro et al (03) and Alokananda $\mathrm{R}$ et al (07). ${ }^{14,22}$

Operative time in our study was less in NDVH compared to TAH (69.84+14.06 $\mathrm{min}$. v/s 77.64-12.92 $\mathrm{min})$ and this is comparable to studies done by Benassi et al (02), Hwang et al (02), Ribeiro et al (03), Raju et al (03), David Soriano (04), Silva Filho et al (06), Komal Modi et al (07). ${ }^{13-15,19,23-25 .}$

In the present study NDVH cases had less febrile morbidity compared to TAH cases, but UTI was more in NDVH compared to TAH cases. Modi K et al (07) had finding comparable to our study. We had no case of paralytic ileus in NDVH compared to $6 \%$ cases in TAH. Wound infection in our study was $4 \%$ in TAH which is comparable to Benassi et al (02), Miskry (03), Ray Aloknanda et al (07), Somjita $\mathrm{C}$ et al (08). ${ }^{17,19,21-23}$ In present study resuturing was needed in $2 \%$ cases of TAH and this is similar to study of Bharatnur S. ${ }^{16}$ Vaginal cuff cellulitis was not seen in our study and no case of vault hematoma was seen in either study group. So fibrile episodes, paralytic ileus, wound infections, wound gap, wound hematoma, re-suturing were seen more in TAH group while UTI and vomiting was more in NDVH group. In the present study most cases in NDVH group (78\%) required analgesia for 3 days post operatively and no case In NDVH group required analgesia beyond 5 days. In TAH cases more than $50 \%$ cases required analgesia beyond 6 days. In studies of Santhini NF et al 2012 and Agarwal A et al analgesia was required for lesser number of days in NDVH cases compared to TAH cases. $^{18,26}$ In the present study most of the cases of NDVH $(66 \%)$ were ambulatory in $<24 \mathrm{hrs}$. post operatively while most cases of TAH (50\%) were ambulatory after $48 \mathrm{hrs}$. Modi $\mathrm{K}$ et al reported that most cases $(85.3 \%)$ of NDVH got ambulatory in 24 hrs. while most cases of TAH (84\%) got ambulatory in 24-48 hrs. ${ }^{19}$ In our study most of the cases $(70 \%)$ of NDVH had post operative hospital stay of 4 days while no case of TAH had post operative hospital stay of less than 4 days. Study of Bharatnur S and Shanthini NF et al reported longer duration of hospital stay in NDVH (9.6 days, 8.1 days respectively) but still it was less than the hospital stay in TAH (11.1 days, 10.9 days respectively). ${ }^{16,18}$

\section{CONCLUSION}

From this study it has was concluded that non descent vagina hysterectomy has benefits over abdominal hysterectomy in terms of:

- Cosmetic advantage, as no visible scar.

- Avoids all discomforts of abdominal incision.

- Shorter operative time.

- Lesser blood loss

- Lesser post-operative morbidity.

- Lesser intra operative and post-operative complications.

- Smooth post-operative period and faster recovery.

- Less requirement of post-operative analgesia.

- Early ambulation

- Enhanced patient comfort

- Short Hospital stay and early discharge.

- Early return to work and normal household activities.

- Lastly in patients with associated medical problems like diabetes mellitus, hypertension and cardiovascular disease, non-descent vaginal hysterectomy is less invasive, acceptable alternative to abdominal hysterectomy.

Funding: No funding sources

Conflict of interest: None declared

Ethical approval: The study was approved by the Institutional Ethics Committee

\section{REFERENCES}

1. Lepine LA, Hillis SD, Kieke BA, Marchbanks PA, Koonin LM, Morrow B, Kieke BA, et al. Hysterectomy surveillance-United States, 19801993. Morbidity and mortality weekly report: CDC Surveillance Summaries. 1997;46(4):1-15.

2. Dicker RC, Greenspan JR, Strauss LT, Cowart MR, Scally MJ, Peterson HB, DeStefano F, et al. Complications of abdominal and vaginal hysterectomy among women of reproductive age in the United States: the collaborative review of sterilization. Am J Obstet Gynec. 1982;144(7):841-8.

3. Wilcox LS, Koonin LM, Pokras R, Strauss LT, Xia Z, Peterson HB, et al. Hysterectomy in the United States, 1988-1990. Obstetrics \& Gynecology. 1994;83(4):549-55.

4. Kovac SR. Guidelines to determine the route of hysterectomy. Obstetrics \& Gynecology. 1995;85(1):18-23.

5. Harris MB, Olive DL. Changing hysterectomy patterns after introduction of laparoscopically assisted vaginal hysterectomy. Am J obstetrics gynecology. 1994;171(2):340-4.

6. Querleu D, Cosson M, Parmentier D, Debodinance P. The impact of laparoscopic surgery on vaginal hysterectomy. J American Association Gynecologic Laparoscopists. 1994;1(4, Part 2):S29-S29. 
7. Weber AM, Lee JC. Use of alternative techniques of hysterectomy in Ohio, 1988-1994. New England J Medicine. 1996;335(7):483-9.

8. Boike GM, Elfstrand EP, DelPriore G, Schumock D, Holley HS, Lurain JR, et al. Laparoscopically assisted vaginal hysterectomy in a university hospital: report of 82 cases and comparison with abdominal and vaginal hysterectomy. Am J obstetrics and gynecology. 1993;168(6):1690-701.

9. Kovac SR. Vaginal hysterectomy. Bailliere's Clin Obstet. Gynecol. 1997;11:95-110.

10. Davies A, Vizza E, Bournas N, O’Connor H, Magos A. How to increase the proportion of hysterectomies performed vaginally. Am J obstetrics gynecology. 1998;179(4):1008-12.

11. Kovac SR, Christie SJ, Bindbeutel GA. Abdominal versus vaginal hysterectomy: a statistical model for determining physician decision making and patient outcome. Medical Decision Making. 1991;11(1):1928.

12. Kovac SR. Guidelines to determine the route of hysterectomy. Obstetrics \& Gynecology. 1995;85(1):18-23.

13. Hwang JL, Seow KM, Tsai YL, Huang LW, Hsieh BC, Lee C. Comparative study of vaginal, laparoscopically assisted vaginal and abdominal hysterectomies for uterine myoma larger than $6 \mathrm{~cm}$ in diameter or uterus weighing at least $450 \mathrm{~g}$ : a prospective randomized study. Acta obstetricia et gynecologica Scandinavica. 2002;81(12):1132-8.

14. Ribeiro SC, Ribeiro RM, Santos NC, Pinotti JA. A randomized study of total abdominal, vaginal and laparoscopic hysterectomy. Int J Gynecology \& Obstetrics. 2003;83(1):37-43.

15. Silva-Filho AL, Werneck RA, de Magalhães RS, Belo AV, Triginelli SA. Abdominal vs vaginal hysterectomy: a comparative study of the postoperative quality of life and satisfaction. Archives gynecology obstetrics. 2006;274(1):21.

16. Bharatnur S. Comparative study of abdominal hysterectomy versus vaginal hysterectomy in non descent cases. Internet $\mathbf{J}$ Gynecology Obstetrics. 2010;15(2).

17. Miskry T, Magos A. Randomized, prospective, double-blind comparison of abdominal and vaginal hysterectomy in women without uterovaginal prolapse. Acta obstetricia et gynecologica Scandinavica. 2003;82(4):351-8.

18. Shanthini NF, Poomalar GK, Jayasree M, Bupathy A. Evaluation of complications of abdominal and vaginal hysterectomy. Int $\mathrm{J}$ Reprod Contraception Obstet Gynaecol. 2012;1(1):7-11.

19. Modi K, Patel S, Gupta S, Barnwal R, Desai A, et al. Non Decent Vaginal Hysterectomy A comparative analysis. IJSR. 2014;3(11):414-6.

20. Coulam CB, Pratt JH. Vaginal hysterectomy: Is previous pelvic operation a contraindication? American journal of obstetrics and gynecology. 1973;116(2):252-60.

21. Chakraborty S, Goswami S, Mukherjee P, Sau M. Hysterectomy.....Which Route? J Obstetrics Gynecology of India. 2011;61(5):554-7.

22. Aloknanda R, Luna P, Roshan B, Chaudhary R. Non-Decent Vaginal Hysterectomy: a constantly Improving surgical Art. J Obstetrics and Gynecology India. 2011;61(2):182-8.

23. Benassi L, Rossi T, Kaihura CT, Ricci L, Bedocchi L, Galanti B, Vadora E. Abdominal or vaginal hysterectomy for enlarged uteri: a randomized clinical trial. Am J obstetrics gynecology. 2002;187(6):1561-5.

24. Raju VS, Girija BS. Comparison of vaginal hysterectomy for non-descent uterus with abdominal hysterectomy. Indian J Public Health Research \& Development. 2014;5(1):15.

25. David Soriano MD Daniel S. Seidman Evidence based Obstetrics \& Gynecology - Vol 6, Issue 1 (March 2004) - Copyright @2004 Churchill.

26. Mahasani V, Suchdeva R, Aggarwal A. Hysterectomy-which approach. People's J Scientific Research. 2014;7(1):17-21.

Cite this article as: Mehta $\mathrm{K}$, Prakash $\mathrm{O}$,

Fatehpuriya DS, Verma L. Comparative study of abdominal hysterectomy and vaginal hysterectomy in non-descent cases a prospective study. Int J Reprod Contracept Obstet Gynecol 2017;6:1265-70. 